\title{
Investigating the poetic view of music in Attar's poetry with emphasis on imaginary forms
}

\section{Investigando la visión poética de la música en la poesía de Attar con énfasis en formas imaginarias}

\author{
Behrooz Nadimi \\ $\mathrm{PhD}$ student, Islamic Azad University, Mashhad Branch iran \\ Reza Ashrafzadeh \\ Professor of Islamic Azad University, Mashhad Branch iran \\ Majid Taghavi Behbahani \\ Professor, Islamic Azad University, Mashhad Branch iran
}

Received 07-08-20 Revised 08-10-20

*Correspondence

Email: BehroozNadimi@gmail.com
Accepted 09-02-20 On line 03-07-21

Cite as:

Nadimi, B., Ashrafzadeh, R., \& Behbahani, M. (2021). Investigating the poetic view of music in Attar's poetry with emphasis on imaginary forms. Propósitos y Representaciones, 9(SPE3), e1108. Doi: http://dx.doi.org/10.20511/pyr2021.v9nSPE3.1108 


\section{Summary}

Imaginations in poets' poetry are the achievement of a kind of experience and awareness that the poet gains from his surroundings. Attar is one of the great mystics and poets of the vast field of Persian literature. With his painful mysticism, he has led the lovers of the path of conduct through seven valleys. Basically, some mystics were closely acquainted with hearing and music, and Attar is one of the most prominent of them. The purpose of this study is to study the forms of imagination in musical applications - terms, words and instruments - Attar's poetry. Studies have shown that Attar has refined his mystical thinking by using the thoughtfulness of musical terms. In this research, the author has extracted verses in which musical terms and instruments have no musical purpose. But from the point of view of imagination and poetic point of view, it was important that it be studied.

Keywords: Attar, music, musical terms, musical instruments. Imaginations, poetic look

\section{Resumen}

Las imaginaciones en la poesía de los poetas son el logro de una especie de experiencia y conciencia que el poeta obtiene de su entorno. Attar es uno de los grandes místicos y poetas del vasto campo de la literatura persa. Con su misticismo doloroso, ha conducido a los amantes del camino de la conducta a través de siete valles. Básicamente, algunos místicos estaban familiarizados con la audición y la música, y Attar es uno de los más destacados. El propósito de este estudio es estudiar las formas de imaginación en aplicaciones musicales - términos, palabras e instrumentos - la poesía de Attar. Los estudios han demostrado que Attar ha refinado su pensamiento místico utilizando la consideración de los términos musicales. En esta investigación, el autor ha extraído versos en los que los términos e instrumentos musicales no tienen finalidad musical. Pero desde el punto de vista de la imaginación y el punto de vista poético, era importante que se estudiara.

Palabras clave: Attar, música, términos musicales, instrumentos musicales. Imaginaciones, mirada poética

\section{Introduction}

Sheikh Farid al-Din Muhammad ibn Ibrahim Attar of Neyshabur is one of the greatest mystics of the sixth and early seventh centuries, and like most mystics, his life is shrouded in a halo of myth. Various theories have been presented about his date of birth, but among all the mentioned dates, the year (539) seems to be more correct and his martyrdom is at the hands of the Mongols and at the time of the massacre of Neishabour in the year (618) "(Ashrafzadeh, 1374: 8). -7).

Attar is one of the mystical poets who has used poetry to explain his mystical thoughts. His immortal mystical Masnavi is an ocean for seekers of the journey to God.

"We do not know of any nation that lacks music. We have to admit that music is a phenomenon in human nature and the factors that lead a person to search for music are the same tensions that made him recite poetry, and the connection between the two is strong. Because poetry is in fact the music of words and words and richness is the music of songs and melodies "(Shafiee Kadkani, 1997: 44).

Tahmasebi considers the word music to mean melody and considers music as a science by which the state of songs is known in terms of pride, tenderness and tension (cf. Tahmasebi, 2001: 27).

Poets have long used musical terms and instruments in their poetry and have used them for various purposes. Sometimes for educational purposes and sometimes for non-educational purposes. In the educational section, musical terms and instruments are used in the same 
conventional meanings and we will not deal with it in this article. But in the non-educational part, sometimes terms and musical instruments are used in meanings other than their original meanings, and this has covered the poetic clothes on the stature of these terms and instruments.

The influence of music and its terms is evident in the works of many poets. Due to their specialized acquaintance with music, some of them have a purely musical view and are devoid of poetic imagination, and some of them have often combined music and related words with their poetic imagination and vision.

In recent centuries, imaginary forms have become more widespread. The field of traditional expression is limited to the four categories of simile, metaphor, irony, and permissibility. In the new definitions of imagination in poetry, the departure from any linguistic norms is considered to be the entry into illustration. According to this definition, myth, symbol, exaggeration, etc., which had no place in the classification of imaginary images of the past, can be placed in the realm of imaginary images (see Shamisa, 1372: 74).

Examining the poetic uses of musical terms and instruments from the perspective of imaginary forms, in addition to further understanding the poetry and thought of poets, will also reveal to us the linguistic capacities.

Imagination in Attar's poems, although sometimes repetitive, is new in terms of attitude. These images can be considered the product of his personal look and experiences.

Among the cases in which Attar's experiences are reflected are images related to musical terms and instruments. He has used these terms in his poetry in various forms and for various purposes.

It is unclear whether Attar knew music or not, and whether he played the instrument or not. But with the garlic in his works; It can be said that: Attar did not follow music technically and professionally and only for the mystical benefit in his poetry, he sought to know the terms and positions of music to some extent (Nadimi, 2012: 12).

Attar's works are not devoid of idioms and terms, positions and musical instruments, and Attar can be considered a poet who has used music for his mystical purposes in poetry.

So far, research has been done on the reflection of musical terms and instruments in the works of Attar and other poets. In these studies, what has been considered are musical terms and instruments, and the authors have merely provided evidence that the musical instrument and vocabulary are mentioned.

Kurdish from the soul of a musicologist

Rise and musician woman in knowledge

Thank you for the tone of the music.

(Mantiq al-Tair, b 622 and 623)

The sequences and repetitions in the above verse, in addition to causing verbal music, have also caused spiritual music by bringing the word music to mind.

The man musicologist has compared the tone and song of creation with music from the bottom of his heart, you too, O musician, rise up and play music in mysticism. Like Moses, you have seen the fire from afar, because you sing on the mountain like Moses and you speak the truth.

The musicologist's man seems to be referring to Plato's enrichment of the curtains Took music out of the song of the movement of the stars and the rotation of the planets (Tharotian, 2005: 189). 
Considering that the Pythagoreans believed that music came from the upper world and the heavens, Attar accordingly knew music from the upper world and the heavens. Rumi has the same thought:

Serna moans and threatens

So the sages have said that these tones are what left the whole naqour

We got it from the spinning wheel

The cry of wheel spins is that of creation

They sing it to the tambourine and to the throat

(Rumi's Masnavi, 1390, Daftar Chahar, 13: 584)

One of the criteria for measuring the relationship between poetry and music is the use and presence of musical terms in poets' poems. An examination of the quantity and quality of these terms shows how familiar the poet was with music. The frequent use of musical words in Attar's poetry indicates that he was familiar with music, and this statement becomes probable when we see the high frequency of specialized musical words in his poetry. In the tragedy, he mentions the number of music curtains (twelve curtains) and names some of them.

Because the oyster had so many feathers

So open ten and two curtains

Blurring was the premise of the work

So that no one can step out of the curtain

The tie deserves the veil of lovers

Because he saw the opposite, he asked for it

Throw that one in Nahavand

So Zafan is a bandit with a razor and a bang

Eventually the burning parting emerged

It makes the horizons new

He straightened the opposite curtain

He threw the other one in the closet

He beat Hosseini to Hassan's song

It emerged from Sepahan and Iraq

(Tragedy, B 91-97) 
In many verses, Attar has looked at musical words from different perspectives and expressed other meanings from them. These uses are so artistic that words accurately represent all their facets.

So far, no independent research has been done on the poetic view of music in Attar's poetry.

Analogy

It is like likening one thing to another or establishing a connection and similarity between two things. Allegory is one of the factors in creating poetic images or images.

"In simile, many contrasting and contradictory things that are far from each other in terms of sense and intellectual experience can be grouped together in one subject. In fact, simile is the embodiment and likeness of something that is absent and It does not appear normally "(Shafiee Kadkani, 1991: 72).

Lake is the joy of death

I kick my foot from the green of the leaves

(Tragedy, B 995)

Beating a foot is likened to a leaf. Here, Attar considers the leaf intoxicated with joy and passion. He refers to the time when he became intoxicated with the joy of death and his feet became like leaves.

Her lovers came clean of imperfections

Because sentence trees came in the dance

(Tragedy, B 2827)

Attar sees nature as lively, dancing and dancing, and in most cases are accompanied by dancing and dancing, trees and leaves and other examples of nature.

His hair fell off when the veil of lovers came

They sang at any time

(Diwan, p. 239)

"Maqam is one of the twelve positions of old music mentioned by Farabi that Arab musicologists and Turks consider it as one of the foundations of their music with some other melodies" (Stayeshgar, 2005: J2 / 669)

Lovers in modern Iranian music are considered to be the main and important corners of the right and Panjgah instruments, Nova, Homayoun and Avaz Dashti.

The attention of poets, writers and speakers to the word love and its relatives such as lover, lover, etc. has caused this word to remain in the ranks of Iranian national music. Attar has paid attention to this music scene.

As mentioned in this verse, the quasi-Zulf aspect of the veil of lovers is the multiplicity and newness through it. Although this aspect seems a bit far-fetched, it can be interpreted by knowing that the lover is one of the main corners of many devices (due to its multiplicity and capacity). "Curtain" also brings to mind the meaning of hijab. 
Chou David Nabi, play this curtain

Chow Davood Ayat Sargoshtegan Khan

Chou Jesus woman breath in love incense

(Divine Letter, b 442)

Psalms of love on the troubled reader

(Secret Letter, B 543)

David was pleased with the voice of the Almighty and played the psalm well. When he sang the psalm aloud, the birds listened to his voice. The poet mentions here to recite the verse of the bewildered like David.

There are a hundred thousand hearts in your pocket

Chubak Zan To Cho Pasbanan

(Diwan, p. 165)

Chubakzan means female drummer and drummer. Lovers are likened to women who are like constables. According to the author, the pseudo-analogy is that the lovers shout your description everywhere.

Shams's articles contain a story by Ibrahim Adham:

"Ibrahim Adham, before leaving the king of Balkh, you spent in this lust of property and obeyed, and you said what should I do? And how is it that it does not open? He slept on the bed until night, awake asleep; And the guards beat the drums and the trumpets and the trumpets and the shouts, he said to himself which enemy are you holding back, that the enemy is sleeping with me! ... »(Shams Tabrizi, 1385: 85).

In many texts, Chubakzan is accompanied by a constable, and this accompaniment is also seen in the meaning of this combination. Attachments are likened to the chubak of women guarding.

Choo was the green song of Golzar

The last drunkenness appeared in the flower

(Divine Letter, B 5848)

Green color; The name of the tone is mentioned. The praiser says:

"Sabzarng has been recorded as attributed to Sheikh Attar's slave and this is also evident from Sheikh's poem, that he called Sabzarrang a tonal name. Hand is wrong and the meaning is green in green "(Stayeshgar, 1375: J2 / 31-30). However, it can be considered the name of a tone - the ninth tone - of the melody of music. As Sabzarang is considered to be the ninth tone of Barbad's gypsy melody in the Sassanid era.

This milk chow beat the drum

Van Chu wolf tore

(Tragedy, B 979)

The sound of the drum is echoed by the roar of the lion and the roar of the wolf.

He was a Hindu Saturn 
Night bell from the moon, his wife's drum

(Tragedy, B 364)

Saturn; It is likened to a Hindu chubak, and the night bell is like a female drum. جوبكى زن; He is a drummer and drummer, and in some cases, he accompanies the constable.

Because Farid sighed like a moan

Every vein of hers is like that

(Diwan, p. 78)

The harp is one of the instruments that has been used more than other instruments in Attar's poetry and it is obvious that he has paid special attention to this instrument and its appearance features. Bending like a harp refers to the shape of the harp, the resonant box of which is curved, and this curvature has found many manifestations in the poetry of poets.

Because my hospitality is like that of Attar

Each breath estimated the following chow moans

(Diwan, p. 168)

What is meant by the moan of the harp is the sound of the harp, and here the following voice.

I am like that with my back bent

Till Buk Chu Cheng sing a tail

(Mokhtarnameh, B 1073)

So Cheng Chun became aware of one nail

(Authorization, p. 753)

Chu grabbed your back and did not realize it

In the above two verses, the quasi-simile aspect is the curvature of the harp, and the poet refers to old age. Many poets have considered the harp as a metaphor for the old.

Because I fell in love with you

Play me with kindness

(Diwan, p. 640)

In this bit, the stature is compared to a harp in terms of curvature. The concept of aging in the love of the beloved is also expressed from the verse, and usually in the poems of poets, the strings of the harp are called veins.

Rag and Pi remained in Fagan like this

Whatever pain I remember from you

Play me who rose without you

The whole brain of Chou dates remained bones 
(Divine Letter B 3157)

Chu Cheng cries out from every vein

(Divine Letter B 84)

Because it grabs every Faghani vein

(Authorization, p. 667)

Until you play Chou Changm

The vein on my body became bloated

(Authorization, p. 202)

The harp vessel in the above verses refers to the harp strings. As the blood flows in the vein and this flow is a sign of life, the strings of the harp flow like the vein of Nova and shout for their survival. Hence, comparing strings to veins is a clever and appropriate metaphor.

It was moaning like that, from anxiety

In the curtain, under the grip of the minnal field

His profession is Rabab

(Disaster Letter, B 6594)

Make me cry once

(Mokhtarnameh, B 1073)

This verse refers to the melody below the harp and the poet considers this melody to be mournful and sad.

Such a grip from the curtain of the heart

We sing in the way of his love

(Authorization, p. 507)

Attar, in some of the similes, is himself one of the parties to the simile (often similar). In such similes, the frequency of the harp is similar to that of the ballast. Curvature, wounding, and in general the appearance and sound of this instrument can be the reasons for the creation of such similes and its high frequency.

Chu was intoxicated by a rabbi

I like him like a rabbi

(Divine Letter, B 5846)

In the culture of recycled, the definition of "rabab" states:

"It is an instrument whose musician has a short and large harp like a harp on which the skin is stretched. It is said that this word is Arabic and its Persian is 'Rawadeh' and the meaning of Ravadeh is a sad song and it has four strings. Because its short handle is at the top, they have said it hand in hand, that is, the cry of women "(Ashrafzadeh, 2007: J1 / 727). 
Repetition and creation of similes from these repetitions, in addition to the verbal beauty of the verse, has also caused its spiritual beauty. In this verse, Attar likens himself to Rabab and considers the pseudo-face to be over his head.

When I become a musician, I cry

I have a difficult task

(Diwan, p. 797)

Musician; Instrumentation from the family of wind instruments is of the oral organ or oral instrument. The musical structure consists of a number of different trumpets placed side by side. There are two types of this instrument: single and multiple.

In continuation of the principles of Iranian music, Forough writes about musicians:

"But the musician or a few tracks that have been recorded in books with different spellings of musician, mesqal, musqar and mesqal are similar to the oral organ. Some people say that this instrument is played by shepherds (Forough, 1354: 94).

In the above verse, Attar likens himself to a musician. As mentioned in the description of this instrument, some have said that this instrument is owned by their dervishes, and perhaps one of the reasons for choosing similar was to accompany this instrument with their dervishes.

Hard beak is wonderfully long

Such a straw has many holes in it

(Mantiq al-Tair, b 2335)

ن : One of the wind instruments is very old and it is made of wood. It is a cylinder that is blown into sound.

The refiner writes:

"This instrument has a special name depending on the material of the cylinder and how it is built and played. If it is made of a pipe that has seven straps, it is called a reed with seven straps. If it is made of plain or wood or metal, it is called simple straw. If it is accompanied by an anvil, it is called anvil trumpet or anvil reed.

If it has a tongue, it has a lip. If it has two languages It is called bilingual reed or serna.

If the blow hole is on the side of the cylinder, it is called both a reed and a flute. If they make it from scratch, it is a straw or a straw. If they are made of gold, it is a golden reed. If they are made of silver, it is called Simin reed "(Mallah, 1997: 697-696).

In this verse, the beak of a phoenix is compared to a straw. In the following verses, Attar refers to the quasi-aspect of this analogy - it is close to a hundred holes in his beak.

Metaphor

A metaphor is a metaphor in which one of its elements (similar or similar) is omitted. "What is important in metaphor and the basis of recognizing the power of the poet's imagination and feeling the pleasure of the beauty of art, is the discovery of new and precise similarities between objects" (Pournamdarian, 1381: 241).

Bang Cheng and moaning Naish ZP

Moderate with each other like milk and may 
(Tragedy, B6791)

Attar used the word "bang" for the sound of the reed and the word "moan" for the sound of the "reed". Today, in addition to the word, looking at metaphor also targets the meaning. "Moaning" is often considered a human present. An action that is accompanied by thinking and understanding suffering. In Persian literature, the trachea has often been a metaphor for man and the human soul.

Fattadeh in Angels Bang and Ghalghl

Fatadeh Ghalghli on the Great Throne

That Tazan Towards Rani Book Deldel

(Secret Letter, B 269)

That came Sadr and Badr of both worlds

(Secret Letter, B 286)

The metaphor is the same sound that is heard from the throat when pouring wine into the cup.

Irony

Poets or writers can perfect their imagination by using irony. Shams Qais says in this regard: "The irony is that because the speaker wants to say the meaning of the meanings, another meaning of the functions and accessories of the first meaning, bring it and refer to it, and this industry is used in words and to Special and general close common "(Shams Qais, 1335: 363).

The nightingale that gives birth to him, the hands of women fall

He will sing to your head, from his hundred glorious tongues

(Diwan, p. 827)

Women's hands The irony of songwriting is singing.

Get up and sing a lyric

When Venus brings Rabab

(Diwan, p. 140)

Singing is a metaphor for singing.

Wounded in the way he straightened

The opposite is true of the right vein

(Divine Letter, B 5849)

Shafi'i Kadkani says about this verse in the description of the divine letter:

"It has considered the right and opposite proportions in music, and the interpretation of straightening a vein is an allusion to relaxation, because when a person becomes angry, his arteries come out of the normal state" (Attar, 2008: Comments, 657-699). 
This verse has two meanings: with the wound he inflicts on the instrument and with the song he sings, he could calm and accompany the opponent as well. Venice; With the wound he inflicted on the instrument, he agreed with the opposite corner.

The array of ambiguity is one of the most widely used industries in innovative knowledge. Ambiguity or obscurity is a sweet form of interpretation; Thus, in the word, a word is given that has two meanings: one close to which the meaning of the word is obvious and the other far away to which the meaning of the word is hidden. The speaker or writer intends the distant meaning because of the hidden analogy, but covers it with the near meaning; In such a way that in the first encounter, the listener or reader considers it as the intention of the speaker (Hamavi, 1426: 2/40, Siouti, 1421: 2/152, desirable, 2000: 217-219 and 433-435).

Curtain to the world of life

The pedestrians return to the screen

(Diwan, p. 252)

"Curtain" has different meanings in music. In ancient music, the names of the twelve maqams of Nova, Rast, Hosseini, Rahavi, Iraq, Hejaz, Zangleh, Busilk, Ashaq, Sepahan, Bozorg and Zir Afkand have been mentioned.

Ameli says about the curtain in Nafais Al-Fonun:

"In the use of the master of music, as the noble dimension was often immersed in it, then he is synonymous with the plural" (Amoli, 1337: 109).

The curtain is mentioned in the meaning of corner, position and branch. The cords that are fastened to the handle of the instrument today are also called curtains.

The distances between the notes are called curtains. For example, the distance between two notes "two" to " $r$ " is called a curtain. In curtain literature, it has been used both in its musical meaning and in its non-musical meaning, which has a hidden meaning. This is also the case in Attar's poetry, that is, both its musical meaning is expressed and its non-musical meaning is understood.

Now I am confused about the horizon

That I became a lover

(Divine Letter, B 5852)

One of the twelve positions of Iranian music is called the position of lovers. The veil of lovers includes both the musical meaning and the meaning of the veil of lovers.

Chrysanthemum throat means opening

Guide the creation from the tone of creation

(Mantiq al-Tair, b 649)

Farabi says:

"The melody and what is attributed to them are among the things that come to the senses and the imagination and the intellect. But whether what is tangible is exactly what is imagined or not, or what is tangible is sometimes imagined and sometimes has a different mood, is a debate that is not limited to tone, but to all things consistent with It includes it "(Farabi, 1375: 12). 
Here, in addition to the non-musical meaning, which is a pleasant song, the tone also brings to mind the musical meaning due to its accompaniment to the throat and David.

The tie deserves the veil of lovers

It makes the horizons new

(Tragedy, B93)

Nova is used in various meanings; 1- Song. 2- Music curtain. 3- One of the twelve old maqams is maqam music. 4- Row Contemporary Music, Nova is one of seven musical instruments.

In the above verse, "Curtain of Lovers" and "Nova" are both ambiguous.

One drunken slave in front of the heart

Farooq said that you will pray later

Because I fell in love with you

Bad left with no self open eyes

(Mantiq al-Tair, b 3895)

Poetry reading

(Tragedy, B799)

Play me with kindness

(Diwan, p. 640)

It is from the Sassanid era. In instrumental music and in the row of Musa, he is famous from the end corners of Homayoun's instrument. It also means caressing the heart. Attar uses this word in his poem and both meanings can be expressed from it.

Eventually the burning parting emerged

It emerged from Sepahan and Iraq

(Tragedy, B 97)

The words Isfahan, Sepahan, Safahan, Espahan all refer to one of the old twelve officials and one of the sad branches of Homayoun.

The word Sepahan is attributed to the historical city of Isfahan. If we examine the various incomes that have come to Isfahan with different narrations, they all have in common that the control note of Isfahan is the first step and the trend of income melody expands to the fourth degree.

It is one of the earlier songs of Iranian music and today it is evident in the line of music with the same name. Iraq is an Iranian name and part of Iran. Iraq is the ninth of the twelve main old positions, but in our time, Iraq is one of the corners of Afshari singing and Mahour, Nova, Rast and Panjgah instruments. 
When we look closely at the last two poets, it can be seen that some poets have mentioned the name of this position and the appropriate branches with it. Nezami and Attar are in the same situation.

The poet says of the burning and pain of a hard separation that has shown its end. According to the ambiguous concept of the second shutter, it can be interpreted in two ways. A reference to the spatial and geographical distance of Isfahan and Iraq that confirms this separation, as well as a reference to the song and song in the musical institutions of Isfahan and Iraq, which are sad and suitable for separation and embarrassment.

Homayi has mentioned in the book of rhetoric and literary techniques:

"It is that the speaker or writer in his speech brings homosexual words that are similar in appearance and in different meanings" (Homayi, 1361: 143).

It is one of the types of verbal beauties of words and poets and writers have used it to color their words (Rak Ashrafzadeh, 2005: 47).

So the secret is hidden

Do not let Chou sing out of the curtain

(Divine Letter, B 2817)

"Curtain" is used in the first stanza, meaning hijab, and in the second stanza, it means "music curtain". This difference in meaning has made the bit beautiful.

What is the last year, Colonel? That moaning card and tone is like moaning

$$
\text { (Theology, b 1464) }
$$

It is a song that rises from inside full of pain and sorrow. Nal is a thin stick in the middle of a straw. "Moan" and "moan" have puns. The consonance of the letters has caused the melody and raised the musical level of the beat.

Wounded in the way he straightened

The opposite is true of the right vein

(Divine Letter, B 5849)

Wounds and wounds in the above bit have phonological proximity and are of the ascending punctuation type. Wound composed of wound $+\mathrm{e}$ after the name of the penis.

A device for playing percussion instruments.

The link between musician and avatar (Stayeshgar, 1374: J1 / 575).

There were thousands of species of nightingales

There was no profit for one hand

(Diwan, p. 735)

In both scenes, the word hands is used in two different meanings. Puns are of the Tom type. 
Theme of creation

Thematicization is one of the important techniques in literature, which is based on poetic imagination and artistic analysis, and of course, it is not unique to poetry.

"We must keep in mind that themes are not found only in linguistic texts. Pantomime images and plays also have their own theme, and even when the text is viewed as a linguistic expression, it is still not necessary that the main theme is clearly mentioned in the text "(Brinker, 2009: 35 And 36).

Thematicization, like the style of the period, is different in different periods. As in the Khorasani style, it is more based on the analogy of the tangible to the tangible type, and in the Iraqi period it is more based on metaphor and recognition, and if it is done with thematic similitude, the similes are more of the tangible type to the sensible. In the Indian style, the themes of the images are mostly formed on the basis of allegory (Hajian, 1396: 257).

In selecting the verses of this section, the author has paid attention to the creation of new and original themes that have emerged using musical instruments and idioms.

The pain of the ten butler of the parliament that we

It is a curtain of pain that we played

(Diwan, p. 488)

Playing the curtain of pain; It is a theme that Attar has created using musical words.

What should I do when my heart disagrees?

I did not come right to play this curtain

(Divine Letter, b 5851)

By using the opposite, right, curtain, playing, as well as the association of the word maker in the verb "sazm", Attar has created a theme that has both a musical load and a non-musical theme.

Rise and musician woman in knowledge

(Mantiq al-Tair, b 622)

Playing an instrument in knowledge and here using a musical instrument is a theme that is made and paid for by Attar.

Diagnosis (Meccan metaphor)

Recognition is a sub-branch of metaphor, the poet animates inanimate elements with his imaginative power. Artistic view of natural phenomena causes the creation of different linguistic phenomena (Mortazavi and Najafi Behzadi, 1390: 188).

Do not go out without clothes

He sings on his happy song

From the inside no singing curtain

(Diwan, 337)

Which is sung in silk and straw 
(Secret Letter, B 449)

Singing is a word that is commonly used for human beings, and singing is also a human present tense. Singing, unlike sound, which can come out of the larynx without any thought, often comes out of the larynx with thought, motivation, and knowledge. Using this word for silk and straw has given them a human face.

Get up and sing a lyric

Why are you so silent Kaflak

When Venus brings Rabab

(Diwan, p. 140)

Your speech is a terrifying dance

(Theology, b / Supplement 556)

\section{Conflict}

Language is a collection of words (words and monosyllabic words). Each morpheme carries a meaning that is used to describe and mean that morpheme. "Contrast is said to be two words that all the characteristics are the same or differ in only one characteristic" (Falk, 1377: 355).

Some have interpreted the relation of contradiction between words as follows: Contradictory words are words that have different forms and meanings against each other (cf. Gharib, 1350: $63)$.

I was free, I was unjust

The opposition was not right-wing to the world

I was a womanizer, she bit my finger

(Diwan, p. 158)

Do not make a curtain under it with a bass

(Divine Letter, B 5850)

Observations such as

The preacher Kashfi Sabzevari in his definition of observance has given: (Preacher Kashfi Sabzevari, 1369: 115 and 116).

Wounded in the way he straightened

The opposite is true of the right vein

(Divine Letter, B 5849)

Confusion of proportion

In ambiguity, sometimes all the meanings derived from the word are meant by the speaker, and sometimes from the two meanings far and near, the opposite definition of the mentioned 
meaning is near meaning, the meaning and distant meaning is ambiguous meaning. Sometimes the axis of ambiguity is such that it does not express several parallel meanings but reminds of semantics, content and other points (Rastgoo, 1379: 13 and 14).

It has a lot of secrets under the curtain

Because he saw the opposite, he asked for it

He does not say he has one and he sings

(Secret Letter, b 1709)

He straightened the opposite curtain

$$
\text { (Tragedy, B 94) }
$$

Rampouri considers the opposition to be a branch of the Iraqi authority and composed of five songs that were played at sunset (Rak, Rampouri, 2009: 794).

The opposite in contemporary music is from the wide corners of the three-part and four-part system. The opposition has at one point been linked to the satanic music of Iran, where the art of taziyeh peaked in Iran. Similarly, the readers are divided into two groups, the pros and cons. The readers agree with the right people and positive historical personalities, and the readers disagree with the cruel and cruel historical people. The vocal tone in favor of the singers is usually sad and in contrast to the vocal tone in opposition to the singers is aggressive and violent.

The probable meaning of the verse is that when he saw the opposite, he also began to read in the opposite veil. In the verses before this verse, Attar refers to the curtains of music and enumerates them.

Wounded in the way he straightened

The opposite is true of the right vein

(Divine Letter, B 5849)

This verse has two meanings: with the wound he inflicts on the instrument and with the song he sings, he could calm and accompany the opponent as well. Venice; With the wound he inflicted on the instrument, he agreed with the opposite corner.

So the razor blade and the cry of the woman

He beat Hosseini to Hassan's song

(Tragedy, B96)

Hosseini is one of the melodies of Iranian music that can be seen in post-Islamic maqami music texts to this day. Farabi has spoken of this position, calling it the basis of Turkish and Arab music.

This verse is also included in the continuation of the verses that Attar refers to the music screens. The poet points out that the singer sings with a good voice in the position (curtain) of Hosseini.

Hassan's song also brings to mind both the meaning of the happy song and the person's name.

Vocabulary 
Phonology is the arrangement and beautification of words that is done by repeating a word (silent) or repeating a vowel (vowel). As we know, consonants are a set of letters and vowels are a set of movements (conquest, addition, fraction) and modal letters (a, e, o) that make them into short and long vowels. Have been named. Repetition of each of these two (consonant and vowel) which is interpreted as phonology or melody of letters (Dehghan Zad and Mirzaei Tabar, 2012: 37).

In this way, the poet consciously creates music and adds to the good effect of creating images and inducing his mood and conveying his message in poetry (Jamali, 2004: 65).

Phrase "s"

There were thousands of species of nightingales

If I am half a muse

There was no profit for one hand

(Diwan, p. 735)

I have a musician in my chest

(Diwan, p. 797)

Vocabulary "Z"

Lamentation is also my speech

It is under my grievance

(Mantiq al-Tair, b 755)

The repetition of the letters in these verses and the music that results from their pronunciation is resonating to the ear familiar to music.

Repetition

In the Najafi Valley, the repetition of the words is called "repetition" or "repetition" and it is written: "Repetition, which is also called repetition and is repeated, this industry is such that they repeat the word or more than twice to emphasize or bow Or warning and punishment and ... (Mirza Sardar, Bita: 132).

Shafi'i Kadkani writes in his critique of this array: "It is the case that a word with the same meaning appears twice in a poem, the vulgar type of which is everyone's work and the opposite type is difficult to see" (Shafiee Kadkani, 1997: 305).

In some verses, Attar has repeated musical words for various purposes. Sometimes for emphasis, sometimes for wording, and sometimes for contextualizing other arrays, and that is why most word repetitions are associated with other arrays.

One of the thousands of David's people died

It was not Zayn al-Han but Zan al-Han

(Diwan, p. 264)

Exaggeration 
In sum, it is an exaggeration to present an image, an image in a broader sense than imagination and image; That is, the expression of a state or a description. Although it has a logical way of expression, with the difference that in the exaggeration of that adjective or state, with the capture that the speaker's mind makes, it changes or becomes smaller or larger than its normal state. ترح. This capture of the mind in enlarging and enlarging the image is not something that affects beauty and ugliness, but sometimes the cause of beauty can be sought in the beauty and appropriateness of the main elements, and sometimes in the removal and addition that is done by the speaker. (Shafiee Kadkani, 1991: 137).

When I heard that great song

I was horrified, my hands were weak

(Divine Letter, b 4573)

Allowed

"Permissible" on the weight of the verb is taken from the jazalshi of yuzuz, meaning the time when it devours from it. In fact, when the word deviates from what the original language has made obligatory for it. It is called permissible because by it they have died from their original position or have violated their original position (Jorjani, 2006: 254).

Refresh my heart to David

Make my psalm famous

(Secret Letter, B 543)

Davoodi songs and melodies are allowed to be pleasant and pleasant songs.

In the dictionary of literary terminology, it is stated: "The beauty of reasoning, in the term of literature, is that the poet gives a pleasant reason for his content but not in accordance with reality. In the terminology of English literature, it is unlikely that a good interpretation of a permissible category is established by means of a metaphor or metaphor between two completely unrelated subjects "(Dad, 2004: 199).

According to what is adapted from different definitions of good reason, the expression of any literary cause for a phenomenon can be considered "good reason".

The musician had a secret

Lamentation is also my speech

The appearance of David was that song

(Tragedy, B 6790)

It is under the grip of my lament

(Mantiq al-Tair, b 755)

Under the harp is one of the four strings and is thinner than the other three strings. Attar blames Nalehzar for the melody below. 
Result

In this article, we took a look at those of Attar's poems that contained a poetic approach to music. In our studies, we have come to the conclusion that literary arrays and fantasies alone constitute a significant part of his poems.

The author examines similes, metaphors, allusions, ambiguities, puns, thematic creation, discernment, contradiction, phonology, observance such as, repetition, exaggeration, permissible and good interpretation in those poems that refer to musical terms and instruments and the direction and They achieved the following poetic side:

Most of the imagination in Attar's poetry is in the service of high mystical concepts.

In the verses extracted from Atta's poetry, the images of any kind - including similes, allusions, metaphors, contradictions, ambiguities, etc. - are clear and simple and far from complexity and ambiguity. The reader easily finds the images in their proper place in the poetic building.

Man and the mystical view of man are not a minor element of poetic treatments in Attar's poetry, but are rooted in the poet's thought and worldview and are a powerful factor in the coherence of his verses and all his poems. Meanwhile, Attar is a mystic poet and mystics are basically familiar with listening to music idioms, but idioms and musical instruments are not the focus of Attar's imagination, although there are several verses in his poetry that refer to idioms and musical instruments and the poetic look is seasoned with these verses. Is.

A significant part of the verses that referred to musical terms and instruments, although used in their normal and original sense, but the poetic choice of musical instruments and terms is not accidental. Attar has created an image in accordance with its characteristics and mission, using each instrument and terminology.

\section{References}

1. Aghasardar, Najafgholi Mirza (1362).. Corrected by Hussein Ahi. Tehran: Foroughi.

2. Ashrafzadeh, Reza (1374). Selected description of the logic of the bird. second edition. Tehran: Myths.

3. 1384) - , - Aesthetic exploration of puns. Journal of Mashhad Azad University. Issue 5.

4. Brinker, Menachem (1388). Theme and interpretation. Translated by Shahrooz Khomjari. Art Quarterly. Issue 79.

5. Pournamdarian, Taghi (1381). Travel in May. Tehran: Negah.

6. Tharwatian, Behrooz (1384). Description of the secret of the logic of the bird; Review and rewrite prose. Tehran: Amirkabir.

7. Jorjani, Abdul Qahir (2006).. To suspend mysticism. First edition. Institute of Cultural Books.

8. Jamali, Shahrooz (1383). Repetition, the basis of poetic music. Cultural Universe. Issue 216.

9. Hajian, Khadijeh (1396). Linguistic reflection on the theme and thematic techniques in Persian poetry. Bimonthly of linguistic essays. No. 2 (consecutive 37).

10. Hamwi, Ibn Hajjah (1426). The treasury of literature and the end of fire. Beirut: AlMuktabah Al-Asriya.

11. Dad, Sima (1383). Dictionary of Literary Terms. Tehran: Morvarid. 
12. Dehghan Zad, Rasoul and Mirzaei Tabar, Azadeh (2012). A study of the musical structure of Hafez Ibrahim's poems. Journal of Arabic Literature. No. 4. Fourth year.

13. Rastgoo, Mohammad (1379). Ambiguity in Persian poetry. Tehran: Soroush.

14. Siouti, Jalaluddin (1421). Al-Atqan in the sciences of the Qur'an. Research by Fawaz Ahmad Zamrli. second edition. Beirut: Dar Al-Kitab Al-Arabi.

15. Shafiee Kadkani, Mohammad Reza (1370). Imagination in Persian poetry. Tehran: Agah.

16. 1376) -). Poetry music. Fifth Edition. Tehran: Naghsh Jahan Publications.

17. Shams Qais Razi (1335). Dictionary in the meanings of non-Arabic poems. Corrected by Allameh Qazvini. Tehran: University of Tehran.

18. Shamisa, Sirus (1381). A fresh look at the novelty. Tehran: Ferdowsi.

19. 1374) — - - Expression and meanings. Tehran: Ferdowsi.

20. 1372) — - - . A fresh look at the novelty. Tehran: Ferdowsi.

21. Tahmasbi, Tughral (1380). Music in Literature. Tehran: Raham.

22. Attar Neyshabouri, Farid al-Din (1383) The logic of the bird. Introduction, correction and comments of Dr. Mohammad Reza Shafiei Kadkani. Tehran: Sokhan Publications.

23. (1387) - - - Introduction, correction and comments of Dr. Mohammad Reza Shafiei Kadkani. Tehran: Sokhan Publications.

24. 1386) - - -) Misibatnameh. Introduction, correction and comments of Dr. Mohammad Reza Shafiei Kadkani. second edition. Tehran: Sokhan Publications.

25. (1386) - - - Introduction, correction and comments of Dr. Mohammad Reza Shafiei Kadkani. Second edition. Tehran: Sokhan Publications.

26. 1386) - - -) Mukhtarnameh. Introduction, correction and comments of Dr. Mohammad Reza Shafiei Kadkani. Third edition. Tehran: Sokhan Publications.

27. (1384) - ‘ - With the care and correction of Taqi Tafazli. Eleventh edition. Tehran: Scientific and cultural publications.

28. Farabi, Abu Nasr (1375). Great music. Tehran: Institute of Humanities and Cultural Studies.

29. Falk, Julia S. (1372). Linguistics and language. Translated by Khosrow Gholam Ali Zadeh. second edition. Mashhad: Astan Quds.

30. Gharib, Abdul Azim (1350). Persian grammar (in collaboration with the Queen of Poets Bahar, Badi-ol-Zaman Forwanfar, Jalaluddin Homayi, Rashid Yasemi). Tehran.

31. Maraghei, Abdul Qadir (1356). مقاصدالالحان. By Taqi Binesh. second edition. Tehran: Book Translation and Publishing Company.

32. Mortazavi, Jamaluddin and Najafi Behzadi, Sajjad (1390). A study and comparison of imaginary forms in the poetry of Hossein Manzavi and Qaisar Aminpour. Quarterly Journal of Language and Literature. Nineteenth year. Issue 70.

33. Matloub, Ahmad (2000). Dictionary of rhetorical terms and their evolution. Beirut: Lebanese School. 
34. Rumi, Jalaluddin Muhammad bin Muhammad (1390). Masnavi. Edited by Reynolds A. Nicholson. Fifth Edition. Tehran: Hermes.

35. Preacher Kashfi Sabzevari, Kamaluddin Hussein (1369). Badaye Al-Afkar Fi Sanaye AlAshaar. Edited and submitted by Mir Jalaluddin Kazazi. Centeral Tehran.

36. Homayi, Jalaluddin (1361). Rhetoric and literary crafts. Tehran: Toos. 